\title{
Photodegradation and adsorption of hexazinone in aqueous solutions: removal efficiencies, kinetics, and mechanisms
}

\author{
Tahereh Jasemizad $^{1} \cdot$ Lokesh P. Padhye $^{1}$ iD
}

Received: 8 October 2021 / Accepted: 9 February 2022 / Published online: 21 February 2022

(c) The Author(s) 2022

\begin{abstract}
Hexazinone, a globally applied broad-spectrum triazine herbicide, has not been mechanistically investigated previously under advanced oxidation processes (AOPs) and adsorption on activated carbon. In this study, its fate during UV-based oxidation with/without hydrogen peroxide $\left(\mathrm{H}_{2} \mathrm{O}_{2}\right)$ and adsorption on coconut shell-based granular activated carbon (CSGAC) in water matrices was investigated. A comparison between various irradiation sources (visible, UVA, UVB, and UVC) revealed the highest degradation rate under UVC. More than $98 \%$ degradation of hexazinone was observed under $3 \mathrm{~J} \mathrm{~cm}^{-2} \mathrm{UVC}$ fluence in the presence of $0.5 \mathrm{mM} \mathrm{H}_{2} \mathrm{O}_{2}$ at $\mathrm{pH}$ 7. Moreover, the degradation rate enhanced significantly with an increase in the initial dosage of $\mathrm{H}_{2} \mathrm{O}_{2}$, UV fluence, and contact time in the $\mathrm{UV} / \mathrm{H}_{2} \mathrm{O}_{2}$ process. The rate of degradation was lower using secondary effluent than that of Milli-Q water due to the presence of dissolved organics in wastewater. However, the reactions in both matrices obeyed pseudo-first-order kinetics. The effect of different scavengers, including methanol, potassium iodide (KI), and tert-butyl alcohol (TBA), showed that hydroxyl radicals $\left({ }^{\circ} \mathrm{OH}\right)$ played a dominant role in hexazinone degradation in the $\mathrm{UV} / \mathrm{H}_{2} \mathrm{O}_{2}$ process. Hexazinone was effectively adsorbed by CSGAC through $\pi-\pi$ electron donor-acceptor interactions between hexazinone's triazine ring and CSGAC's surface functional groups. The isotherm and kinetic studies showed that the adsorption followed the Freundlich model and pseudo-second-order reaction, respectively, suggesting chemisorption. This study provided mechanistic insights on the removal of hexazinone at the tertiary stage of wastewater treatment or the advanced treatment of wastewater reuse.
\end{abstract}

Keywords Hexazinone $\cdot \mathrm{UV} / \mathrm{H}_{2} \mathrm{O}_{2} \cdot$ Adsorption $\cdot$ Kinetics $\cdot$ Isotherms $\cdot$ Mechanisms

\section{Introduction}

Over the past few decades, pesticides have been extensively applied in intensive agriculture practices, which has substantially contributed to an increase in the pollution of surface water and groundwater (Adak et al. 2019; Padhye et al. 2013). Hexazinone, a globally used broad-spectrum triazine (Mei et al. 2012; Yao et al. 2019), is considered the most water-soluble triazine herbicide $(33 \mathrm{~g} / \mathrm{L})$ and is transported to groundwater and surface water near agricultural areas, where it is widely applied (Ganapathy 1996; Martins et al. 2015). It was first registered by the United

Responsible Editor: Sami Rtimi

Lokesh P. Padhye

1.padhye@auckland.ac.nz

1 Department of Civil and Environmental Engineering, The University of Auckland, Auckland, New Zealand
States Environmental Protection Agency (US EPA) in 1975 for weed control and classified as a group D carcinogen. It can also cause throat, eye, and nose irritation (Martins et al. 2014). It is unsusceptible to photolysis, hydrolysis, and microbial degradation, adding to its persistence in the aquatic environment and resulting in serious environmental concerns (Bouchard et al. 1985; Mei et al. 2012; Yao et al. 2019). Its concentrations in the aquatic environment have been reported to range from $15 \mathrm{ng} \mathrm{L}^{-1}$ to $400 \mu \mathrm{g} \mathrm{L}-1$ (Calegari et al. 2018). Figure 1 shows the structure of hexazinone.

Due to the widespread presence of toxic pesticide residues in water resources, more efforts are required to eliminate these contaminants from polluted water (Adak et al. 2019). Advanced oxidation processes (AOPs) and adsorption onto activated carbon (AC) are considered as the most common treatment methods for removal of trace levels of emerging contaminants, including pesticides, from water and wastewater (Kwon et al. 2015; 


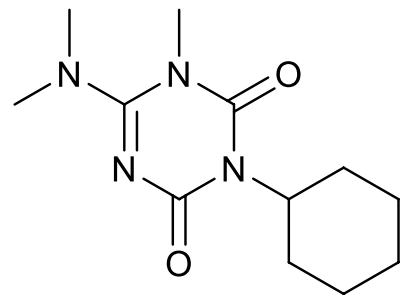

Fig. 1 Chemical structure of hexazinone

Salman and Hameed 2010). AOPs are considered fast, clean, and effective treatments for the mineralization of contaminants from aqueous solutions. Those rely on the formation of hydroxyl radicals $\left({ }^{\bullet} \mathrm{OH}\right)(\mathrm{Jasemi} \mathrm{Zad}$ et al. 2018). However, the complete mineralization of parent compounds may not be possible in AOPs due to the formation of intermediates or degradation products (Agüera and Fernández-Alba 1998). Ultraviolet (UV) irradiation in combination with hydrogen peroxide $\left(\mathrm{H}_{2} \mathrm{O}_{2}\right)$ is one of the main ${ }^{\bullet} \mathrm{OH}$-based AOPs used for water treatment (Autin et al. 2012; Jazić et al. 2020; Jasemizad et al. 2021). In this process, the organic contaminants can be degraded through direct photolysis, indirect photolysis, and/or oxidation by $\mathrm{H}_{2} \mathrm{O}_{2}$ (Liao et al. 2016; Yao et al. 2013; Jasemizad et al. 2021).

Adsorption onto AC, as the most conventional treatment method, is frequently applied for the removal of pesticides (Adak et al. 2019). Compared to other granular AC, coconut shell-based granular AC (CSGAC) demonstrates a larger adsorption capacity due to its high surface area. This advantage makes it an ideal adsorbent for the adsorption of many organic contaminants from aqueous solutions (Padhye et al 2010).

The photodegradation and photocatalytic degradation of hexazinone have been previously reported in the UV/ $\mathrm{H}_{2} \mathrm{O}_{2}$ process under acidic conditions (Martins et al. 2014) and $\mathrm{UV} / \mathrm{TiO}_{2}$ process (Mei et al. 2012), respectively. However, its fate under AOPs and adsorption on CSGAC has not been mechanistically investigated, especially under environmentally relevant conditions. The aim of this study was, therefore, to investigate the fate of hexazinone during photolysis with $\mathrm{UV} / \mathrm{H}_{2} \mathrm{O}_{2}$ and adsorption onto commercial CSGAC. In addition, the effect of different environmental parameters, with a focus on the kinetics and reaction mechanisms, on the removal of hexazinone during advanced oxidation and adsorption was also examined.

\section{Materials and methods}

\section{Chemicals}

Hexazinone was purchased from Sigma-Aldrich, New Zealand. Acetonitrile and methanol (HPLC/MS grade with 99.9\% purity), sodium hydroxide $(\mathrm{NaOH}), \mathrm{H}_{2} \mathrm{O}_{2}$ (30 wt.\% in $\mathrm{H}_{2} \mathrm{O}$, ACS reagent), ammonium formate ( $\geq 99 \%$ purity, used for the preparation of the aqueous UPLC-MS/MS eluent), tert-butyl alcohol (TBA, 99.5\%), and potassium iodide (KI, 99\%) were all purchased from Sigma-Aldrich, New Zealand. CSGAC (Acticarb GC1200, 4×8 mesh) was from Activated Carbon Technologies, New Zealand. Cellulose acetate syringe filters $(0.22 \mu \mathrm{m})$ and 5 -mL syringes were purchased from Thermo Fisher Scientific, New Zealand. Milli-Q water was obtained from a Millipore Milli-Q ${ }^{\circledR}$ water system (resistivity $18.2 \mathrm{M} \Omega . \mathrm{cm}$ ). All other chemicals used in this study were of analytical grade and commercially available.

\section{Experimental procedure}

A stock solution of hexazinone $(1 \mathrm{mM})$ was prepared in water and stored in the refrigerator $\left(4^{\circ} \mathrm{C}\right)$. The photolysis and adsorption experiments were carried out with $0.5 \mu \mathrm{M}$ of hexazinone. All batch experiments were conducted at room temperature $\left(25^{\circ} \mathrm{C}\right)$. The secondary wastewater effluent was collected from the Mangere wastewater treatment plant (WWTP), Auckland, New Zealand. The effluent was first filtered through a $0.22 \mu \mathrm{m}$ membrane and stored at $4{ }^{\circ} \mathrm{C}$ prior to use. The effluent samples were spiked with $0.5 \mu \mathrm{M}$ hexazinone. The $\mathrm{pH}$ was adjusted using $0.1 \mathrm{~N} \mathrm{NaOH}$ and $\mathrm{HCl}$ and measured with a pH meter (HACH, HQ40d) calibrated with buffer solutions at $\mathrm{pH} 4,7$, and 10. Reactions for UV irradiation were carried out from $8 \mathrm{~s}$ to $23 \mathrm{~min}$, corresponding to 0.05 to $9 \mathrm{~J} \mathrm{~cm}^{-2} \mathrm{UV}$ fluence, respectively. $\mathrm{H}_{2} \mathrm{O}_{2}$ stock with $500 \mathrm{mM}$ initial concentration was daily prepared. Sodium sulfite $(100 \mathrm{mM})$ was added at the end of the reaction to quench the residual $\mathrm{H}_{2} \mathrm{O}_{2}$ (Jasemizad et al. 2021). All experiments were carried out in duplicates. Error bars in all the graphs illustrate the maximum and minimum measurements.

\section{UV photolysis}

All the UV-based experiments were performed in a UV chamber (Opsytec Dr. Grobel, Germany) equipped with eight low-pressure lamps (15 W) (Philips Co., Japan), which 
emitted light primarily at $254 \mathrm{~nm}$ (UVC), $313 \mathrm{~nm}$ (UVB), and $352 \mathrm{~nm}$ (UVA). Radiometric sensors were used to measure the intensity of each lamp. The UV fluence was calculated using the following equation:

UV fluence $\left(\mathrm{mJ} \mathrm{cm}^{-2}\right)=\mathrm{UV}$ intensity $\left(\mathrm{mW} \mathrm{cm}^{-2}\right) \times$ exposure time $(s)$

For the $\mathrm{UV} / \mathrm{H}_{2} \mathrm{O}_{2}$ process, $\mathrm{H}_{2} \mathrm{O}_{2}$ was added just prior to the irradiation. The sample solutions were continuously mixed with a magnetic stirrer during the experiments.

\section{Adsorption}

In this study, CSGAC was used as an adsorbent to perform the adsorption tests. The characterizations of the adsorbent have been presented in our previous work and are as follows: BET surface area $\left(984 \mathrm{~m}^{2} \mathrm{~g}^{-1}\right)$, micropore volume $\left(0.39 \mathrm{~m}^{3} \mathrm{~g}^{-1}\right)$, mesopore volume $\left(0.029 \mathrm{~m}^{3} \mathrm{~g}^{-1}\right)$, elemental analysis for carbon (85.9\%), oxygen $(10.7 \%)$, hydrogen $(0.8 \%)$, nitrogen $(<0.3 \%)$, sulfur $(<0.3 \%)$, and total ash content (2.6\%) (Astuti et al. 2021). The adsorbent was first washed with Milli-Q water and then dried at $110^{\circ} \mathrm{C}$ in an oven for $24 \mathrm{~h}$ ( $\mathrm{Yu}$ et al. 2016). After being cooled at ambient temperature, the adsorbent was contacted with $100 \mathrm{~mL}$ of $0.5 \mu \mathrm{M}$ hexazinone solutions at $\mathrm{pH}$ 7.5. The samples were taken at predetermined intervals of time, filtered, and analyzed for the final concentrations of hexazinone.

The amounts of hexazinone adsorbed $\left(\mu \mathrm{g} \mathrm{g}^{-1}\right)$ at time $\mathrm{t}$ $\left(\mathrm{q}_{\mathrm{t}}\right)$ and at equilibrium $\left(\mathrm{q}_{\mathrm{e}}\right)$ were calculated using the following equations:

$q_{t}=\frac{\left(C_{0}-C_{t}\right) V}{W}$

$q_{e}=\frac{\left(C_{0}-C_{e}\right) V}{W}$

where $C_{0}, C_{t}$, and $C_{e}\left(\mu \mathrm{g} \mathrm{L}^{-1}\right)$ are the concentrations of hexazinone at initial, time $t$, and equilibrium, respectively; $W(g)$ is the amount of adsorbent used; and $V(L)$ is the volume of the solution.

The kinetic studies were carried out at different contact times ranging from $2 \mathrm{~min}$ to $32 \mathrm{~h}$ in the presence of $0.1 \mathrm{~g} \mathrm{CSGAC}$. For the isotherm studies, different dosages of CSGAC from $3.12 \mathrm{mg}$ to $0.2 \mathrm{~g}$ were used during $24 \mathrm{~h}$ contact time.

\section{Analytical methods and quantification of aqueous hexazinone}

The quantification of aqueous hexazinone was performed with liquid chromatography-tandem mass spectrometry (LC-MS/MS) (Shimadzu, Japan). The separation was done on a $2.1 \times 100 \mathrm{~mm}, 3.5 \mu \mathrm{m}$, Eclipse Plus C18, Agilent column. The details of LC-MS/MS conditions were described previously (Jasemizad and Padhye 2019).

\section{Results and discussion}

\section{Photodegradation of hexazinone with and without $\mathrm{H}_{2} \mathrm{O}_{2}$}

The effect of the addition of $\mathrm{H}_{2} \mathrm{O}_{2}$ on the degradation of hexazinone under irradiation by different light sources at neutral $\mathrm{pH}$ is shown in Fig. 2. Photolysis alone (no addition of $\mathrm{H}_{2} \mathrm{O}_{2}$ ) showed a low degradation rate $(0.4 \%$ to $17 \%)$. However, a significant increase in the degradation of hexazinone was observed by the addition of $\mathrm{H}_{2} \mathrm{O}_{2}$, particularly under UVB and UVC (Fig. 2). Visible light did not degrade hexazinone with or without $\mathrm{H}_{2} \mathrm{O}_{2}$. Previously, hexazinone was shown to be resistant to the photolysis alone at pH 2.8 (Martins et al. 2014), but the information under environmentally relevant $\mathrm{pH}$ was lacking. The generation of reactive ${ }^{\bullet} \mathrm{OH}$ from $\mathrm{H}_{2} \mathrm{O}_{2}$ under irradiation results in the degradation of organic contaminants (Kim et al. 2009; Wang et al. 2017; Jasemizad et al. 2021). Similar results for other pesticides have been reported in the literature. For example, the addition of $\mathrm{H}_{2} \mathrm{O}_{2}$ into the photolysis system resulted in significant degradation of alachlor (Jazić et al. 2020) and 2,4-dichlorophenoxyacetic acid (Adak et al. 2019). Since the highest hexazinone degradation was observed under UVC irradiation, with and without $\mathrm{H}_{2} \mathrm{O}_{2}$, the rest of the experiments were performed under UVC (254 nm).

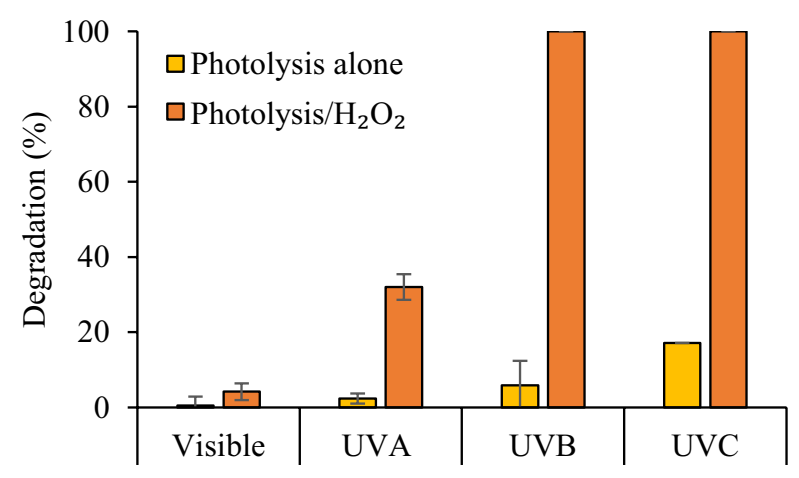

Fig. 2 Visible/UV irradiation with and without $\mathrm{H}_{2} \mathrm{O}_{2}$ ([hexazinone $]_{0}=0.5 \mu \mathrm{M}, \mathrm{pH}=7, \mathrm{H}_{2} \mathrm{O}_{2}=0.5 \mathrm{mM}$, irradiation fluence for visible light $=14, \mathrm{UVA}=24, \mathrm{UVB}=30$, and $\mathrm{UVC}=9 \mathrm{~J} \mathrm{~cm}^{-2}$ ) 


\section{The effect of contact time and UV fluence}

Figure 3 shows the degradation of hexazinone under irradiation and $\mathrm{H}_{2} \mathrm{O}_{2}$ alone and in the $\mathrm{UV} / \mathrm{H}_{2} \mathrm{O}_{2}$ process at different contact times from $8 \mathrm{~s}$ to $23 \mathrm{~min}$, which corresponded to UV fluence from 0.05 to $9 \mathrm{~J} \mathrm{~cm}^{-2}$. Hexazinone showed low $(<20 \%)$ degradation by UV alone and $\mathrm{H}_{2} \mathrm{O}_{2}$ alone. Its degradation increased to $100 \%$ by increasing the UV exposure time from $8 \mathrm{~s}$ to $7.7 \mathrm{~min}$ in the presence of $\mathrm{H}_{2} \mathrm{O}_{2}$ (Fig. 3). In the $\mathrm{UV} / \mathrm{H}_{2} \mathrm{O}_{2}$ process, the target compounds are broken down either by irradiation alone (photolysis), by $\mathrm{H}_{2} \mathrm{O}_{2}$, or by - $\mathrm{OH}$ (Jasemizad et al. 2021). In the system with $\mathrm{H}_{2} \mathrm{O}_{2}$ or UV irradiation alone, hexazinone degradation was less than $20 \%$, which means the direct photolysis and $\mathrm{H}_{2} \mathrm{O}_{2}$ oxidation alone is impractical for hexazinone degradation (Fig. 3). Hence, the complete degradation of hexazinone in the $\mathrm{UV} / \mathrm{H}_{2} \mathrm{O}_{2}$ process is mainly via ${ }^{\circ} \mathrm{OH}$ formation. In this system, two - $\mathrm{OH}$ are produced per photon absorbed by $\mathrm{H}_{2} \mathrm{O}_{2}$ at $254 \mathrm{~nm}$ (Autin et al. 2012; Martins et al. 2014). These radicals are powerful oxidants, which can rapidly react with many organic contaminants, leading to their effective degradation (Jasemizad et al. 2021).

An increase in the UV intensity in the $\mathrm{UV} / \mathrm{H}_{2} \mathrm{O}_{2}$ process results in the greater production of ${ }^{\bullet} \mathrm{OH}$ from $\mathrm{H}_{2} \mathrm{O}_{2}$, which are responsible for the mineralization of organic compounds (Jasemizad et al., 2021). Similar results have been observed for other pesticides. An increase in the degradation of alachlor from 50 to about $95 \%$ was observed by increasing the UV fluence from 200 to $2000 \mathrm{~mJ} \mathrm{~cm}{ }^{-2}$ in the $\mathrm{UV} / \mathrm{H}_{2} \mathrm{O}_{2}$ process at pH 8 in the presence of $0.3 \mathrm{mM} \mathrm{H}_{2} \mathrm{O}_{2}$ (Jazić et al. 2020). In another study conducted by Adak et al. (2019), the degradation of $0.45 \mathrm{mM}$ of 2,4-D increased from 65 to $100 \%$ in the same system by increasing the time from 1 to $10 \mathrm{~min}$ (UV dose from 100 to $1200 \mathrm{~mJ} \mathrm{~cm}^{-2}$ ) at $\mathrm{pH}$ 4 with $1.125 \mathrm{mM}$ of $\mathrm{H}_{2} \mathrm{O}_{2}$. Almost complete degradation of mecoprop herbicide was observed under $800 \mathrm{~mJ} \mathrm{~cm}^{-2}$ UV fluence and $0.15 \mathrm{mM} \mathrm{H}_{2} \mathrm{O}_{2}$. Metaldehyde pesticide also

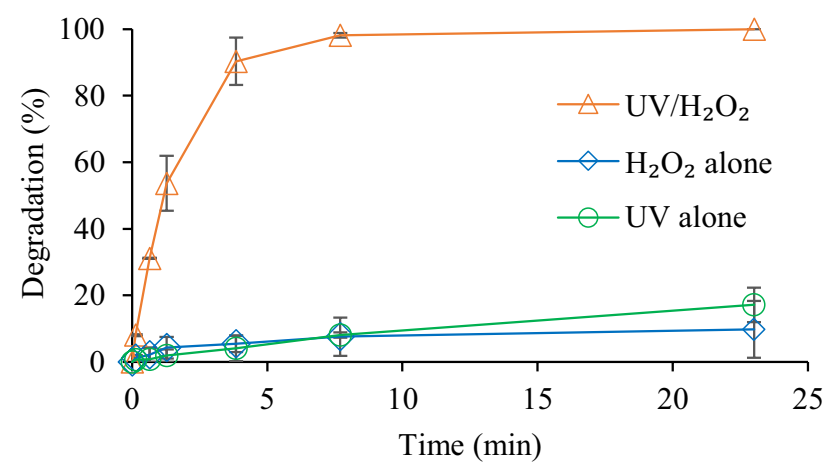

Fig. 3 Effect of contact time on degradation of hexazinone ([hexazinone $]_{0}=0.5 \mu \mathrm{M}, \mathrm{pH}=7, \mathrm{H}_{2} \mathrm{O}_{2}$ dosage $=0.5 \mathrm{mM}$, UV intensity $=6.5 \mathrm{~mJ} \mathrm{~cm}^{-2}$ ) required $1000 \mathrm{~mJ} \mathrm{~cm}^{-2} \mathrm{UV}$ fluence and $0.45 \mathrm{mM} \mathrm{H}_{2} \mathrm{O}_{2}$ for 98\% degradation (Semitsoglou-Tsiapou et al. 2016). UV fluence required for $>90 \%$ hexazinone removal, observed in this study, is within the range reported in the literature for other pesticides. However, considering the real-world UV fluence is in the range of 40 to $140 \mathrm{~mJ} \mathrm{~cm}{ }^{-2}$ for typical disinfection (Kim et al. 2009) and up to $540 \mathrm{~mJ} \mathrm{~cm}^{-2}$ for control of organic pollutants in wastewater (Kruithof et al. 2007), our results showed that hexazinone would not be removed entirely through commonly practiced AOP parameters at the tertiary stage of wastewater treatment.

\section{The matrix effect and kinetic studies}

Figure 4 shows the degradation rate of hexazinone in the $\mathrm{UV} / \mathrm{H}_{2} \mathrm{O}_{2}$ process for Milli-Q water and secondary effluent matrices. The maximum hexazinone removal in the effluent was found to be only $64 \%$ at the contact time of $23 \mathrm{~min}$. The decay rate of hexazinone in secondary wastewater effluent $\left(k=0.06 \mathrm{~min}^{-1}\right)$ was lower than that in Milli-Q water $\left(k=0.52 \mathrm{~min}^{-1}\right)$. This can be explained due to the presence of organic and inorganic compounds in wastewater that can react with ${ }^{\circ} \mathrm{OH}$ and decrease its efficiency for the degradation of individual contaminants (Kumar et al. 2021; Jasemizad et al. 2021).

The $\mathrm{k}_{\mathrm{obs}}\left(\mathrm{min}^{-1}\right)$ value for photodegradation of hexazinone in both Milli-Q water and wastewater matrices (Eq. 4) was calculated from the plot $\mathrm{Ln}\left(\mathrm{C} / \mathrm{C}_{0}\right)$ vs time (Fig. 4), where $C_{0}$ and $C$ are the initial concentration of hexazinone and its concentration after degradation at time $t$ (min), respectively.

$\operatorname{Ln}\left(\frac{C}{C_{0}}\right)=-\mathrm{k}_{\mathrm{obs}} \cdot \mathrm{t}$

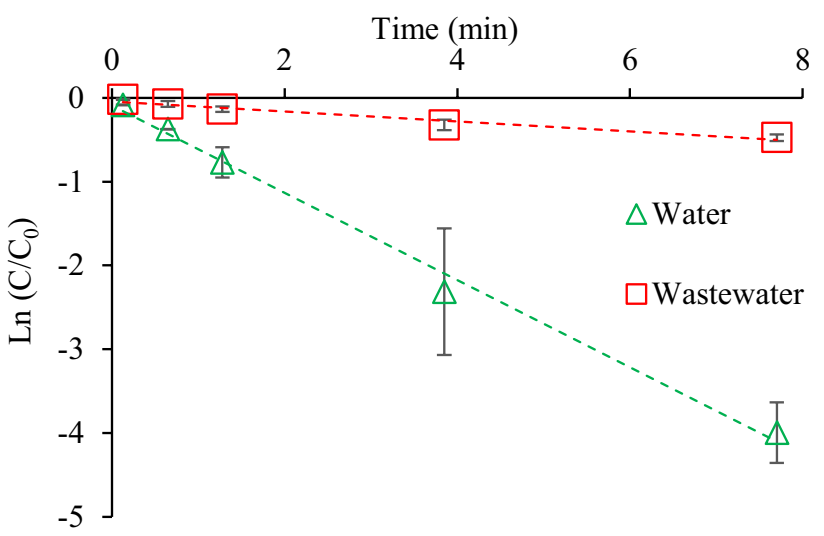

Fig. 4 The pseudo-first-order kinetic for hexazinone ([hexazinone $]_{0}=0.5 \mu \mathrm{M}, \mathrm{pH}=7, \mathrm{H}_{2} \mathrm{O}_{2}$ dosage $=0.5 \mathrm{mM}$, UV intensity $=6.5 \mathrm{~mJ} \mathrm{~cm}^{-2}$ ) 
$\mathrm{H}_{2} \mathrm{O}_{2}$ :hexazinone molar ratio in this study's $\mathrm{UV} / \mathrm{H}_{2} \mathrm{O}_{2}$ experiments was 1000:1; hence, the $\mathrm{K}_{\text {obs }}$ can be assumed to be independent of $\mathrm{H}_{2} \mathrm{O}_{2}$ and ${ }^{\bullet} \mathrm{OH}$ concentrations. The straight lines obtained for hexazinone degradation in Fig. 4, with regression coefficient $\left(R^{2}\right)>0.96$, confirmed that the degradation of hexazinone in the $\mathrm{UV} / \mathrm{H}_{2} \mathrm{O}_{2}$ process followed the pseudo-first-order reaction kinetics. In the literature, some other pesticides were also shown to follow the pseudo-first-order degradation kinetics for the $\mathrm{UV} / \mathrm{H}_{2} \mathrm{O}_{2}$ treatment (Oancea and Meltzer 2014; Ulu 2019; Castro-Narváez et al. 2020; Li et al. 2011; Jazić et al. 2020; Adak et al. 2019). The pseudo-first-order kinetic was also suitable for modelling hexazinone's degradation in the $\mathrm{UV} / \mathrm{TiO}_{2}$ process (Mei et al. 2012).

\section{The effect of varying $\mathrm{H}_{2} \mathrm{O}_{2}$ dosages}

Figure 5 shows the effect of different concentrations of $\mathrm{H}_{2} \mathrm{O}_{2}$ with/without UV irradiation. As evident from Fig. 5, the degradation of hexazinone increased from 50 to $92 \%\left(\mathrm{k}_{\mathrm{H} 2 \mathrm{O} 2}=3.29 \mathrm{mM}^{-1}\right)$ by increasing the dosage of $\mathrm{H}_{2} \mathrm{O}_{2}$ from 0.01 to $0.5 \mathrm{mM}$ under $1,500 \mathrm{~mJ} \mathrm{~cm}^{-2} \mathrm{UV}$ fluence. This increase in the degradation of hexazinone in the presence of a higher concentration of $\mathrm{H}_{2} \mathrm{O}_{2}$ under $\mathrm{UV}$ irradiation can be explained by the absorption of more UV photons by a higher amount of $\mathrm{H}_{2} \mathrm{O}_{2}$, which results in the generation of more radicals. Similar results have been reported in the literature. For example, an increase in the degradation rate of tartrazine, with $10.35 \mu \mathrm{M}$ initial concentration, was observed by increasing the concentrations of $\mathrm{H}_{2} \mathrm{O}_{2}$ from about 0.1 to $0.4 \mathrm{mM}$. In that study, researchers found that by increasing the concentration of $\mathrm{H}_{2} \mathrm{O}_{2}$ to $0.67 \mathrm{mM}$, the degradation of tartrazine decreased and was lower than $0.4 \mathrm{mM} \mathrm{H}_{2} \mathrm{O}_{2}$ (Oancea and Meltzer 2014). High concentrations of $\mathrm{H}_{2} \mathrm{O}_{2}$ have

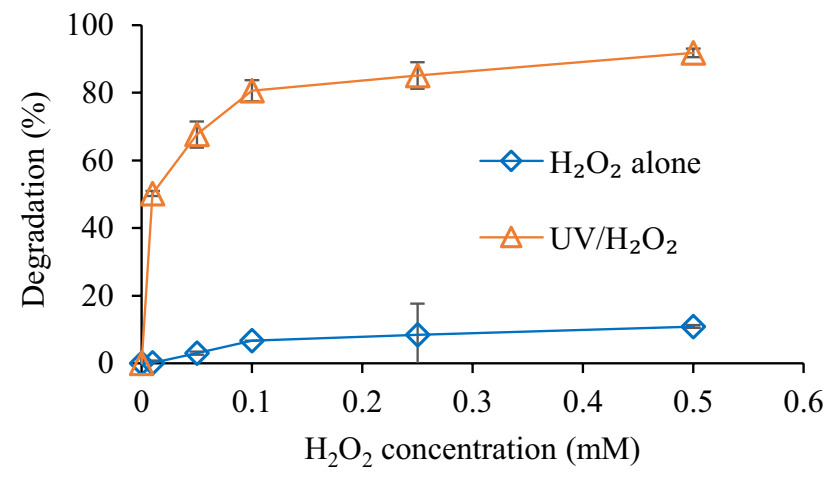

Fig. 5 Effect of the $\mathrm{H}_{2} \mathrm{O}_{2}$ dosage on degradation of hexazinone ([hexazinone $]_{0}=0.5 \mu \mathrm{M}, \mathrm{pH}=7, \mathrm{UV}$ fluence $=1.5 \mathrm{~J} \mathrm{~cm} \mathrm{~cm}^{-2}$, $\mathrm{H}_{2} \mathrm{O}_{2}$ alone contact time $=30 \mathrm{~min}, \mathrm{UV} / \mathrm{H}_{2} \mathrm{O}_{2}$ process contact time $=3.8 \mathrm{~min}$ ) been shown to cause a negative effect on the degradation rate of target compounds, which could be owing to the scavenging impact of $\mathrm{H}_{2} \mathrm{O}_{2}$ on ${ }^{\circ} \mathrm{OH}$ ( $\mathrm{Li}$ et al. 2011; Wang et al. 2017). However, since the concentrations of $\mathrm{H}_{2} \mathrm{O}_{2}$ used in the present study were below the scavenging points reported in the literature, such a decline in degradation was not observed in this study. Moreover, our results confirmed that $\mathrm{H}_{2} \mathrm{O}_{2}$ alone is not suitable for the degradation of hexazinone, with the highest observed degradation of only $11 \%$.

\section{The effect of $\mathrm{pH}$}

The initial $\mathrm{pH}$ of the aqueous solution exhibits different effects on the reactivity of contaminants and, hence, the overall efficiency of the AOPs. In this study, the effect of various pHs (3-11) on hexazinone degradation was assessed at $0.5 \mathrm{mM}$ of $\mathrm{H}_{2} \mathrm{O}_{2}$ and $1 \mathrm{~J} \mathrm{~cm}^{-2}$ of UV fluence. As shown in Fig. 6, hexazinone degradation was highest $(91 \%)$ at acidic $\mathrm{pH}$ and lowest (20\%) at basic $\mathrm{pH}$. Hexazinone has a pKa of 2.2 and was neutral for the tested $\mathrm{pH}$ range. It is reported that in the neutral form, molecules have strong light absorption and high photochemical reactivity, which results in high removal efficiency (Borowska et al. 2015). The decrease in the degradation of hexazinone under alkaline conditions can be explained by two competing processes: the generation of ${ }^{\bullet} \mathrm{OH}$ and the scavenging of ${ }^{\bullet} \mathrm{OH}$ (Sharma et al. 2015). The formation of hydroperoxide anion $\left(\mathrm{HO}_{2}{ }^{-}\right)$(Eq. 5), which is favorable at higher $\mathrm{pH}$ values, can enhance the generation of ${ }^{\bullet} \mathrm{OH}$ in the $\mathrm{UV} / \mathrm{H}_{2} \mathrm{O}_{2}$ process (Eq. 6). On the other hand, $\mathrm{HO}_{2}{ }^{-}$can also act as a scavenger of ${ }^{\circ} \mathrm{OH}$ (Eq. 7) with a faster reaction rate than $\mathrm{H}_{2} \mathrm{O}_{2}$ (Eq. 8). Furthermore, $\mathrm{H}_{2} \mathrm{O}_{2}$ loses its characteristics as an oxidant due to its reaction with $\mathrm{HO}_{2}{ }^{-}$(Eq. 9) (Narayanasamy and Murugesan 2014; Xiao et al. 2016).

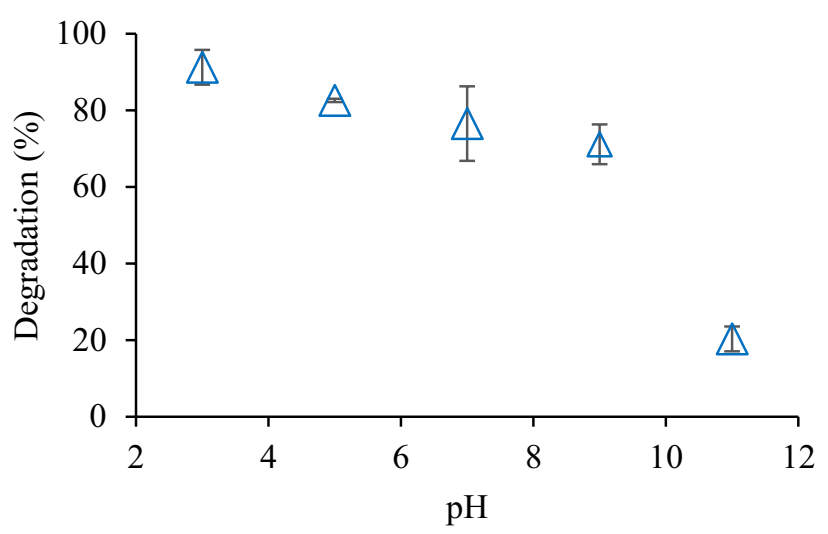

Fig. 6 Effect of $\mathrm{pH}$ ([hexazinone $]_{0}=0.5 \mu \mathrm{M}, \mathrm{H}_{2} \mathrm{O}_{2}$ dosage $=0.5 \mathrm{mM}$, $\mathrm{UV}$ fluence $=1 \mathrm{~J} \mathrm{~cm}^{-2}$ ) 
$\mathrm{H}_{2} \mathrm{O}_{2} \leftrightarrow \mathrm{HO}_{2}^{-}+\mathrm{H}^{+}(\mathrm{pKa}=11.6)$

$\mathrm{HO}_{2}^{-}+\mathrm{H}^{+} \rightarrow 2^{\bullet} \mathrm{OH}$

$\mathrm{HO}_{2}^{-}+{ }^{\bullet} \mathrm{OH} \rightarrow \mathrm{HO}_{2}^{\cdot}+\mathrm{OH}^{-}\left(k=7.5 \times 10^{9} \mathrm{M}^{-1} \mathrm{~S}^{-1}\right)$

$\mathrm{H}_{2} \mathrm{O}_{2}+{ }^{\cdot} \mathrm{OH} \rightarrow \mathrm{HO}_{2}^{\cdot}+\mathrm{H}_{2} \mathrm{O}\left(k=2.7 \times 10^{7} \mathrm{M}^{-1} \mathrm{~S}^{-1}\right)$

$\mathrm{HO}_{2}^{-}+\mathrm{H}_{2} \mathrm{O}_{2} \rightarrow \mathrm{H}_{2} \mathrm{O}+\mathrm{O}_{2}+\mathrm{HO}$

\section{The effect of scavengers}

The effect of $0.1 \mathrm{M}$ of methanol, TBA, and $\mathrm{KI}$, known ${ }^{\bullet} \mathrm{OH}$ scavengers (Kumar et al. 2021; Jasemizad et al. 2021), in the $\mathrm{UV} / \mathrm{H}_{2} \mathrm{O}_{2}$ experiments was evaluated in this study to assess the contribution of ${ }^{\bullet} \mathrm{OH}$ to hexazinone degradation. As can be seen from Fig. 7, the photodegradation of hexazinone in the $\mathrm{UV} / \mathrm{H}_{2} \mathrm{O}_{2}$ process was significantly hindered by the addition of radical scavengers. The degradation rate of hexazinone in the presence of KI $\left(k=0.007 \mathrm{~min}^{-1}\right)$ and TBA $\left(k=0.006 \mathrm{~min}^{-1}\right)$ was almost similar as $\mathrm{H}_{2} \mathrm{O}_{2}$ alone $\left(k=0.004 \mathrm{~min}^{-1}\right)$. In addition, methanol $\left(k=0.001 \mathrm{~min}^{-1}\right)$ showed the highest inhibitory effect on hexazinone degradation in the $\mathrm{UV} / \mathrm{H}_{2} \mathrm{O}_{2}$ process (Fig. 7 and Fig. S2). Results demonstrated the important role of ${ }^{\bullet} \mathrm{OH}$ in hexazinone degradation during AOPs. Ran et al. (2014) had previously demonstrated that TBA could effectively scavenge the ${ }^{\bullet} \mathrm{OH}$ in the ozone $/ \mathrm{H}_{2} \mathrm{O}_{2}$ process for hexazinone degradation.

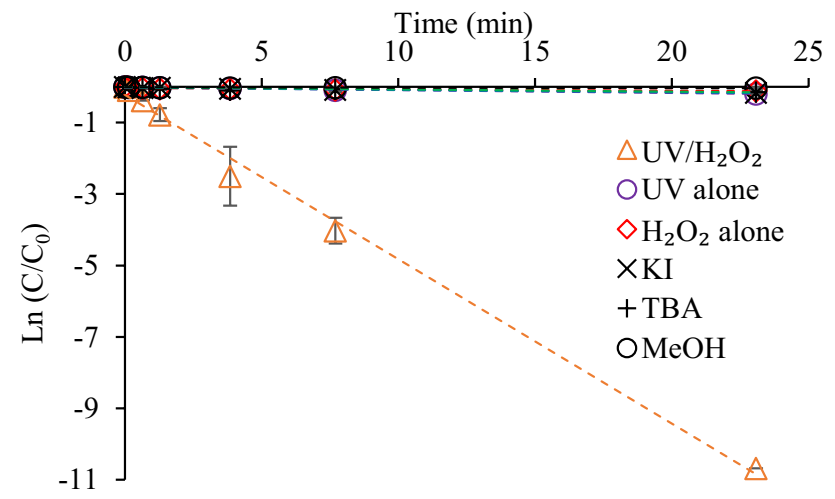

Fig. 7 Hexazinone degradation kinetics in $U V / \mathrm{H}_{2} \mathrm{O}_{2}$ process ([hexazinone $]_{0}=0.5 \mu \mathrm{M}, \mathrm{pH}=7, \mathrm{H}_{2} \mathrm{O}_{2}$ dosage $=0.5 \mathrm{mM}$, scavengers Conc. $=0.1 \mathrm{M}$, UV intensity $=6.5 \mathrm{~mW} \mathrm{~cm}^{-2}$ )

\section{Proposed photodegradation pathways in the presence of hydrogen peroxide}

The identification of the intermediate by-products of hexazinone photodegradation during the $\mathrm{UV} / \mathrm{H}_{2} \mathrm{O}_{2}$ process was carried out by LC-MS/MS using the MS full scan and spectra (Fig. S3). The oxidation of $10 \mu \mathrm{M}$ hexazinone was conducted at various irradiation times under $6.5 \mathrm{~mW} \mathrm{~cm} \mathrm{~cm}^{-2} \mathrm{UVC}$ irradiation in the presence of $0.1 \mathrm{mM} \mathrm{H}_{2} \mathrm{O}_{2}$ at neutral $\mathrm{pH}$. The identified photodegradation by-products from hexazinone were $\mathrm{m} / \mathrm{z}$ 267 and 239, which were previously identified for photocatalytic degradation of hexazinone in the $\mathrm{UV} / \mathrm{TiO}_{2}$ process (Mei et al. 2012). Although smaller intermediates $(\mathrm{m} / \mathrm{z} 241,223$, $147,102)$ were not detected in the present study, the possible photodegradation of hexazinone is expected to be similar to the pathway presented by Mei et al. (2012), due to the dominant - $\mathrm{OH}$ degradation pathway even for the current study. In Mei et al. study, about $20 \mu \mathrm{M}$ hexazinone was completely degraded within $40 \mathrm{~min}$ of exposure to UV irradiation in the presence of $\mathrm{TiO}_{2}$ under neutral pH. Yao et al. (2019) identified a few more intermediates from 70 min electrochemical degradation of hexazinone, with ${ }^{\bullet} \mathrm{OH}$ as a primary oxidant. Those included $\mathrm{m} / \mathrm{z} 305,301,267,261,255,253,241,239,237,225,223$, $217,91,74$, and 60 .

\section{Adsorption of hexazinone on CSGAC}

The adsorption of hexazinone on CSGAC was performed at different contact times, demonstrating an improvement in the removal of hexazinone with time. The adsorption enhanced from 2 to $64 \%$ by increasing the time from $2 \mathrm{~min}$ to $3 \mathrm{~h}$, and then gradually reached equilibrium at $24 \mathrm{~h}$ (Fig. 8) with $~ 95 \%$ adsorption. The higher adsorption at the initial stages of the process can be due to the larger surface area available on CSGAC. At the later stages of the adsorption, the pores of the adsorbent get saturated with hexazinone molecules. Furthermore, there are repulsive forces between the molecules in the solution and

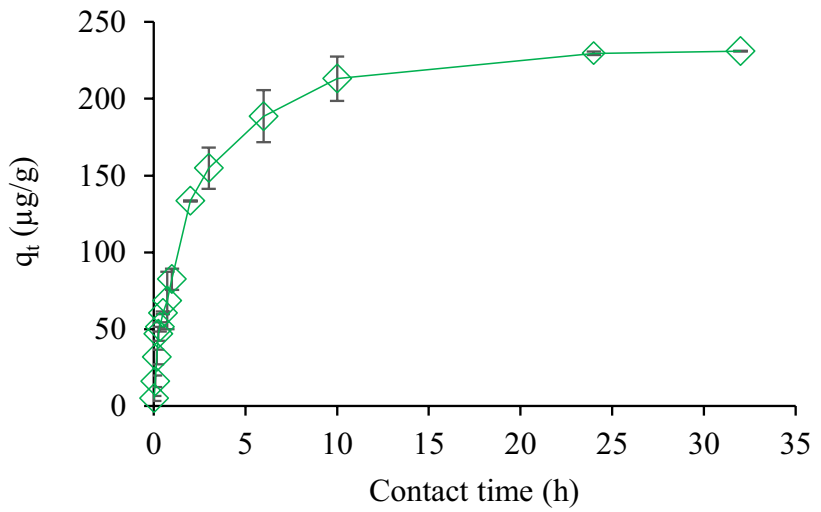

Fig. 8 Effect of contact time on the adsorption rate of hexazinone $(0.5 \mu \mathrm{M})$ onto $0.1 \mathrm{~g} \mathrm{CSGAC}$ at $\mathrm{pH} 7.5$ 
the molecules on CSGAC at the later stages (Njoku et al. 2014; Salman et al. 2011), which lowers the adsorption rate.

\section{Adsorption kinetics}

Adsorption kinetics are strongly related to the physical and/ or chemical properties of the adsorbent (Tan et al. 2015). To understand the adsorption mechanism of hexazinone on CSGAC, the pseudo-first-order (Eq. 10) and pseudo-secondorder (Eq. 11) kinetic models (Jasemizad et al. 2021) were studied (Fig. S4).

$$
\begin{aligned}
& \operatorname{Ln}\left(\mathrm{q}_{\mathrm{e}}-\mathrm{q}_{\mathrm{t}}\right)=\mathrm{Lnq}_{\mathrm{e}}-\mathrm{k}_{1} \mathrm{t} \\
& \frac{\mathrm{t}}{\mathrm{q}_{\mathrm{t}}}=\frac{1}{\mathrm{k}_{2} \mathrm{q}_{\mathrm{e}}^{2}}+\frac{1}{\mathrm{q}_{\mathrm{e}}} \mathrm{t}
\end{aligned}
$$

where $k_{1}\left(\mathrm{~min}^{-1}\right)$ and $k_{2}\left(\mathrm{~g} \mathrm{mg}^{-1} \mathrm{~min}^{-1}\right)$ are the rate constants of pseudo-first-order and the pseudo-second-order reactions, respectively, and $t(\mathrm{~min})$ is the contact time. The kinetic model parameters are listed in Table 1 . The pseudo-secondorder model with $R^{2}>0.99$ best describes the adsorption kinetics of hexazinone onto CSGAC. Moreover, the agreement between the experimental $\mathrm{q}_{\mathrm{e}}$ value and the calculated $\mathrm{q}_{\mathrm{e}}$ value in pseudo-second-order kinetic confirmed the suitability of this kinetic model. It suggested that the adsorption rate depended more on the availability of the adsorption sites on the adsorbent rather than hexazinone concentration in the solution (Njoku et al. 2014; Salman et al. 2011). A similar observation has been reported for the adsorption of some pesticides onto GAC (Salman and Hameed 2010), coconut fronds AC (Njoku et al. 2014), and banana stalk AC (Salman et al. 2011). Furthermore, the pseudo-second-order kinetic suggested that the rate-limiting step is controlled by chemisorption, resulting in the chemical bonding between hexazinone molecules and the functional groups on the surface of CSGAC (Tan et al. 2015).

\section{Adsorption isotherms}

To better understand the adsorption behavior of hexazinone onto CSGAC, two typical isotherm models, Freundlich (Eq. 12) and Langmuir (Eq. 13), were investigated (Table 2 and Fig. S5) (Foo and Hameed 2010).

$q_{e}=K_{f} C_{e}^{1 / n}$

$q_{e}=\frac{q_{m} K_{L} C_{e}}{1+k_{L} C_{e}}$

where $q_{\mathrm{e}}$ is the amount of hexazinone adsorbed per $\mathrm{g}$ of CSGAC $\left(\mu \mathrm{g} \mathrm{g}^{-1}\right)$ and $C_{\mathrm{e}}$ is the equilibrium concentration $\left(\mu \mathrm{g} \mathrm{L}^{-1}\right) . \mathrm{K}_{\mathrm{f}}$ and $\mathrm{K}_{\mathrm{L}}$ are the Freundlich constant $\left(\mu \mathrm{g} \mathrm{g}^{-1}\right)(\mathrm{L}$

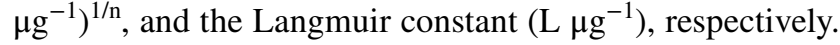
The parameter $\mathrm{q}_{\mathrm{m}}$ is the maximum adsorption capacity $(\mu \mathrm{g}$ $\mathrm{g}^{-1}$ ), and $n$ is a measure of adsorption linearity.

The adsorption of hexazinone onto CSGAC was best described by the Freundlich model with the highest $R^{2}$, suggesting that the adsorption of hexazinone onto CSGAC involves multi-layer adsorption with interactions of the adsorbates' molecules with the heterogeneous surface of adsorbent (Foo and Hameed 2010; Salman et al. 2011). Moreover, this can be confirmed by the $n$ values $(n>1)$ in the Freundlich model, representing higher intensity and favorability for chemisorption (Foo and Hameed 2010; Sumaraj et al. 2020).

\section{Proposed adsorption mechanism}

The mechanism of hexazinone adsorption could be attributed to the interactions between CSGAC surface functional groups, confirmed through FTIR analysis, and hexazinone's triazine ring through $\pi-\pi$ electron donor-acceptor interactions. The adsorption of several pesticides onto activated
Table 1 Comparison of the pseudo-first-order and pseudosecond-order adsorption rate

\begin{tabular}{|c|c|c|c|c|c|c|c|}
\hline \multirow{2}{*}{$\begin{array}{l}\mathrm{C}_{0} \\
\left(\mu \mathrm{g} \mathrm{L} \mathrm{L}^{-1}\right)\end{array}$} & \multirow[t]{2}{*}{${ }^{*} \mathrm{q}_{\mathrm{e} \exp }\left(\mu \mathrm{g} \mathrm{g}^{-1}\right)$} & \multicolumn{3}{|c|}{ Pseudo-first order } & \multicolumn{3}{|c|}{ Pseudo-second order } \\
\hline & & $\begin{array}{l}{ }^{*} \mathrm{q}_{\mathrm{e} \mathrm{cal}} \\
\left(\mu \mathrm{g} \mathrm{g}^{-1}\right)\end{array}$ & $k_{1}\left(\min ^{-1}\right)$ & $R^{2}$ & $\begin{array}{l}\mathrm{q}_{\mathrm{e} \mathrm{cal}} \\
\left(\mu \mathrm{g} \mathrm{g}^{-1}\right)\end{array}$ & $K_{2}\left(\mathrm{~g} \mathrm{mg}^{-1} \mathrm{~min}^{-1}\right)$ & $R^{2}$ \\
\hline 240.16 & 229 & 187.2 & 0.005 & 0.982 & 243 & 0.046 & 0.998 \\
\hline
\end{tabular}
constants
$* \mathrm{q}_{\mathrm{e} \text { exp }}$ and $\mathrm{q}_{\mathrm{e} \text { cal }}(\mu \mathrm{g} \mathrm{g}-1)$ are experimental and model-predicted adsorption capacity at time $t$ 
Table 2 Sorption isotherm parameters of hexazinone onto CSGAC

\begin{tabular}{|c|c|c|c|c|c|c|}
\hline \multicolumn{3}{|l|}{ Freundlich } & \multicolumn{4}{|l|}{ Langmuir } \\
\hline 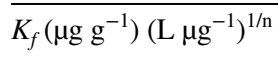 & $n$ & $R^{2}$ & $\overline{K_{L}\left({\left.\mathrm{~L} \mu g^{-1}\right)}^{-1}\right.}$ & $R_{L}$ & $q_{m}\left(\mu \mathrm{g} \mathrm{g}^{-1}\right)$ & $R^{2}$ \\
\hline 62.52 & 2.03 & 0.987 & 0.041 & 0.165 & 714.3 & 0.95 \\
\hline
\end{tabular}

carbon cloth had been attributed to the dispersion forces between the $\pi$ electrons in pesticide structure and $\pi$ electrons in the adsorbent. Moreover, the aromatic ring in the structure of the pesticides was assumed to enhance the probability of such interactions owing to the delocalization of $\pi$ electrons over the ring (Ayranci and Hoda 2005).

\section{Conclusions}

In this study, the performance of the UV irradiation with/ without $\mathrm{H}_{2} \mathrm{O}_{2}$ and adsorption on CSGAC for the removal of hexazinone in aqueous solutions was examined. The results indicated that the photodegradation rate of hexazinone could be enhanced by the addition of $\mathrm{H}_{2} \mathrm{O}_{2}$ in the presence of $\mathrm{UV}$, particularly under UVC irradiation, due to the formation of more ${ }^{\bullet} \mathrm{OH}$ from $\mathrm{H}_{2} \mathrm{O}_{2}$. However, $\mathrm{UV}$ and $\mathrm{H}_{2} \mathrm{O}_{2}$ individually were not effective for hexazinone degradation. Moreover, an increase in the irradiation time, UV fluence, and $\mathrm{H}_{2} \mathrm{O}_{2}$ concentration could significantly improve the degradation rate. The photodegradation of hexazinone in the $\mathrm{UV} / \mathrm{H}_{2} \mathrm{O}_{2}$ process followed the pseudo-first-order kinetic reactions. The effect of ${ }^{\bullet} \mathrm{OH}$ scavengers, including methanol, KI, and TBA, confirmed the significant role of ${ }^{\circ} \mathrm{OH}$ in the degradation of hexazinone during AOPs. Our results show that hexazinone removal in real-world AOP conditions could be problematic, considering the low levels of oxidants used as well as the presence of other organics in secondary effluents which scavenge ${ }^{\bullet} \mathrm{OH}$. However, adsorption could be an effective treatment for hexazinone removal. Almost complete adsorption of hexazinone was achieved in the presence of $0.1 \mathrm{~g}$ of CSGAC within $24 \mathrm{~h}$. The adsorption kinetic and isotherm models of hexazinone fitted the pseudo-second-order and Freundlich curves, respectively. The main adsorption mechanism of hexazinone on CSGAC was found to be chemisorption. The findings of the study provide helpful information to researchers and practitioners regarding hexazinone removal at advanced stages of wastewater treatment and/or reuse.

Supplementary Information The online version contains supplementary material available at https://doi.org/10.1007/s11356-022-19205-y.

Acknowledgements Tahereh Jasemizad would like to thank The University of Auckland for providing her $\mathrm{PhD}$ scholarship to undertake the project.

Author contributions Tahereh Jasemizad: Conceptualization, visualization, investigation, validation, writing-original draft, response to reviewers. Lokesh P. Padhye: Supervision, conceptualization, visualization, validation, writing, review and editing, response to reviewers, funding acquisition, correspondence. All authors read and approved the final manuscript.

Funding Open Access funding enabled and organized by CAUL and its Member Institutions. This study was financially supported by The University of Auckland PhD scholarship.

Data availability Not applicable.

\section{Declarations}

Ethics approval and consent to participate Not applicable.

Consent for publication Not applicable.

Competing interests The authors declare no competing interests.

Open Access This article is licensed under a Creative Commons Attribution 4.0 International License, which permits use, sharing, adaptation, distribution and reproduction in any medium or format, as long as you give appropriate credit to the original author(s) and the source, provide a link to the Creative Commons licence, and indicate if changes were made. The images or other third party material in this article are included in the article's Creative Commons licence, unless indicated otherwise in a credit line to the material. If material is not included in the article's Creative Commons licence and your intended use is not permitted by statutory regulation or exceeds the permitted use, you will need to obtain permission directly from the copyright holder. To view a copy of this licence, visit http://creativecommons.org/licenses/by/4.0/.

\section{References}

Adak A, Das I, Mondal B, Koner S, Datta P, Blaney L (2019) Degradation of 2, 4-dichlorophenoxyacetic acid by UV 253.7 and UV$\mathrm{H}_{2} \mathrm{O}_{2}$ : Reaction kinetics and effects of interfering substances. Emerg Contam 5:53-60. https://doi.org/10.1016/j.emcon.2019. 02.004

Agüera A, Fernández-Alba AR (1998) GC-MS and LC-MS evaluation of pesticide degradation products generated through advanced oxidation processes: An overview. Analusis 26(6):123-130. https:// doi.org/10.1051/analusis:199826060123

Astuti MP, Jasemizad T, Padhye LP (2021) Surface modification of coconut shell activated carbon for efficient solid-phase extraction of N-nitrosodimethylamine from water. J Sep Sci 44(2):618-627. https://doi.org/10.1002/jssc.202000868

Autin O, Hart J, Jarvis P, MacAdam J, Parsons SA, Jefferson B (2012) Comparison of $\mathrm{UV} / \mathrm{H}_{2} \mathrm{O}_{2}$ and $\mathrm{UV} / \mathrm{TiO}_{2}$ for the degradation of metaldehyde: Kinetics and the impact of background organics. Water Res 46(17):5655-5662. https://doi.org/10.1016/j.watres. 2012.07.057 
Ayranci E, Hoda N (2005) Adsorption kinetics and isotherms of pesticides onto activated carbon-cloth. Chemosphere 60(11):1600 1607. https://doi.org/10.1016/j.chemosphere.2005.02.040

Borowska E, Felis E, Miksch K (2015) Degradation of sulfamethoxazole using UV and $\mathrm{UV} / \mathrm{H}_{2} \mathrm{O}_{2}$ processes. J Adv Oxid Technol 18:69-77. https://doi.org/10.1515/jaots-2015-0109

Bouchard D, Lavy T, Lawson E (1985) Mobility and Persistence of Hexazinone in a Forest Watershed. J Environ Qual 14(2):229-233. https://doi.org/10.2134/jeq1985.00472425001400020015x

Calegari RP, Mendes KF, Martins BC, Pimpinato RF, Baptista AS , Tornisielo VL (2018) Removal of diuron and hexazinone from public water supply using a filter system. Planta Daninha 36. https://doi.org/10.1590/S0100-83582018360100147

Castro-Narváez S, Vielma-Balanta L, Quiñonez J N, Jaramillo-Aguirre A. Electrochemical monitoring of the oxidative degradation of glyphosate with $\mathrm{UV} / \mathrm{H}_{2} \mathrm{O}_{2}$. Journal of Physics: Conference Series, 1541 (2020) 012018. https://doi.org/10.1088/1742-6596/1541/1/ 012018

Foo KY, Hameed BH (2010) Insights into the modeling of adsorption isotherm systems. Chem Eng J 156(1):2-10. https://doi.org/10. 1016/j.cej.2009.09.013

Ganapathy C (1996) Environmental fate of hexazinone. Environmental Monitoring \& Pest Management Branch, Department of Pesticide Regulation Sacramento, CA, 1-15.

JasemiZad TJ, Astuti MP, Padhye LP (2018) Fate of Environmental Pollutants. Water Environ Res 90(10):1104-1170. https://doi.org/ 10.2175/106143018X15289915807191

Jasemizad T, Padhye LP (2019) Simultaneous analysis of betrixaban and hexazinone using liquid chromatography/tandem mass spectrometry in aqueous solutions. MethodsX 6:1863-1870. https:// doi.org/10.1016/j.mex.2019.07.028

Jasemizad T, Bromberg L, Padhye LP (2021) The fate of aqueous betrixaban during adsorption, photolysis, and advanced oxidation: Removal, kinetics, and reaction mechanisms. J Water Process Eng 44:102430. https://doi.org/10.1016/j.jwpe.2021.102430

Jazić JM, Đurkić T, Bašić B, Watson M, Apostolović T, Tubić A, Agbaba J (2020) Degradation of a chloroacetanilide herbicide in natural waters using UV activated hydrogen peroxide, persulfate and peroxymonosulfate processes. Environ Sci Water Res Technol 6(10):2800-2815. https://doi.org/10.1039/D0EW00358A

Kim I, Yamashita N, Tanaka H (2009) Photodegradation of pharmaceuticals and personal care products during $\mathrm{UV}$ and $\mathrm{UV} / \mathrm{H}_{2} \mathrm{O}_{2}$ treatments. Chemosphere 77(4):518-525. https://doi.org/10.1016/j. chemosphere.2009.07.041

Kruithof JC, Kamp PC, Martijn BJ (2007) $\mathrm{UV} / \mathrm{H}_{2} \mathrm{O}_{2}$ treatment: A practical solution for organic contaminant control and primary disinfection. Ozone Sci Eng 29(4):273-280. https://doi.org/10. 1080/01919510701459311

Kumar R, Akbarinejad A, Jasemizad T, Fucina R, Travas-Sejdic J, Padhye LP (2021) The removal of metformin and other selected PPCPs from water by poly(3,4-ethylenedioxythiophene) photocatalyst. Sci Total Environ 751:142302. https://doi.org/10.1016/j. scitotenv.2020.142302

Kwon M, Kim S, Yoon Y, Jung Y, Hwang TM, Lee J, Kang JW (2015) Comparative evaluation of ibuprofen removal by $\mathrm{UV} / \mathrm{H}_{2} \mathrm{O}_{2}$ and $\mathrm{UV} / \mathrm{S}_{2} \mathrm{O}_{8}{ }^{2-}$ processes for wastewater treatment. Chem Eng $\mathrm{J}$ 269:379-390. https://doi.org/10.1016/j.cej.2015.01.125

Li C, Gao NY, Li W (2011) Photochemical degradation of typical herbicides simazine by $\mathrm{UV} / \mathrm{H}_{2} \mathrm{O}_{2}$ in aqueous solution. Desalination Water Treat 36(1-3):197-202. https://doi.org/10.5004/dwt.2011. 2410

Liao QN, Ji F, Li JC, Zhan X, Hu ZH (2016) Decomposition and mineralization of sulfaquinoxaline sodium during $\mathrm{UV} / \mathrm{H}_{2} \mathrm{O}_{2}$ oxidation processes. Chem Eng J 284:494-502. https://doi.org/10.1016/j. cej.2015.08.150
Martins AS, Ferreira TCR, Carneiro RL, Lanza MRV (2014) Simultaneous Degradation of Hexazinone and Diuron Herbicides by $\mathrm{H}_{2} \mathrm{O}_{2} / \mathrm{UV}$ and Toxicity Assessment. J Braz Chem Soc. https://doi. org/10.5935/0103-5053.20140184

Martins AS, Vasconcelos VM, Ferreira TC, Pereira-Filho ER, Lanza MR (2015) Simultaneous degradation of diuron and hexazinone herbicides by photo-fenton: Assessment of concentrations of $\mathrm{H}_{2} \mathrm{O}_{2}$ and $\mathrm{Fe}^{2+}$ by the response surface methodology. J Adv Oxid Technol 18(1):9-14. https://doi.org/10.1515/jaots-2015-0101

Mei M, Du Z, Xu R, Chen Y, Zhang H, Qu S (2012) Photocatalytic degradation of hexazinone and its determination in water via UPLC-MS/MS. J Hazard Mater 221-222:100-108. https://doi. org/10.1016/j.jhazmat.2012.04.018

Narayanasamy L, Murugesan T (2014) Degradation of Alizarin Yellow $\mathrm{R}$ using $\mathrm{UV} / \mathrm{H}_{2} \mathrm{O}_{2}$ advanced oxidation process. Environ Prog Sustain Energy 33(2):482-489. https://doi.org/10.1002/ep.11816

Njoku V, Islam MA, Asif M, Hameed BH (2014) Preparation of mesoporous activated carbon from coconut frond for the adsorption of carbofuran insecticide. J Anal Appl Pyrolysis 110:172180. https://doi.org/10.1016/j.jaap.2014.08.020

Oancea P, Meltzer V (2014) Kinetics of tartrazine photodegradation by $\mathrm{UV} / \mathrm{H}_{2} \mathrm{O}_{2}$ in aqueous solution. Chem Pap 68(1):105-111. https:// doi.org/10.2478/s11696-013-0426-5

Padhye L, Wang P, Karanfil T, Huang C-H (2010) Unexpected role of activated carbon in promoting transformation of secondary amines to N-nitrosamines. Environ Sci Technol 44(11):4161-4168. https://doi.org/10.1021/es903916t

Padhye LP, Kim J-H, Huang C-H (2013) Oxidation of dithiocarbamates to yield $N$-nitrosamines by water disinfection oxidants. Water Res 47(2):725-736. https://doi.org/10.1016/j.watres.2012.10.043

Ran ZL, Sun C, Li SF, Craig DW, Trevor JH (2014) Different Performances of $\mathrm{H}_{2} \mathrm{O}_{2}$ to Oxidize Aldicarb and Hexazinone in the Advanced Oxidation Process of Ozone/Hydrogen Peroxide. J Donghua Univ 31:348-353

Salman J, Hameed B (2010) Adsorption of 2, 4-dichlorophenoxyacetic acid and carbofuran pesticides onto granular activated carbon. Desalination 256(1-3):129-135. https://doi.org/10.1016/j.desal. 2010.02.002

Salman J, Njoku V, Hameed B (2011) Adsorption of pesticides from aqueous solution onto banana stalk activated carbon. Chem Eng J 174(1):41-48. https://doi.org/10.1016/j.cej.2011.08.026

Semitsoglou-Tsiapou S, Templeton MR, Graham NJ, Hernandez Leal L, Martijn BJ, Royce A, Kruithof JC (2016) Low pressure UV/ $\mathrm{H}_{2} \mathrm{O}_{2}$ treatment for the degradation of the pesticides metaldehyde, clopyralid and mecoprop - Kinetics and reaction product formation. Water Res 91:285-294. https://doi.org/10.1016/j.watres. 2016.01.017

Sharma J, Mishra IM, Kumar V (2015) Degradation and mineralization of Bisphenol A (BPA) in aqueous solution using advanced oxidation processes: $\mathrm{UV} / \mathrm{H}_{2} \mathrm{O}_{2}$ and $\mathrm{UV} / \mathrm{S}_{2} \mathrm{O}_{8}\left({ }^{2-}\right)$ oxidation systems. J Environ Manage 156:266-275. https://doi.org/10.1016/j.jenvm an.2015.03.048

Sumaraj XZ, Sarmah AK, Padhye LP (2020) Acidic surface functional groups control chemisorption of ammonium onto carbon materials in aqueous media. Sci Total Environ 698:134193. https://doi.org/ 10.1016/j.scitotenv.2019.134193

Tan X, Liu Y, Zeng G, Wang X, Hu X, Gu Y, Yang Z (2015) Application of biochar for the removal of pollutants from aqueous solutions. Chemosphere 125:70-85. https://doi.org/10.1016/j.chemo sphere.2014.12.058

Ulu HB (2019) Removal of chloridazon herbicide from wastewaters using $\mathrm{Fe} / \mathrm{H}_{2} \mathrm{O}_{2}, \mathrm{UV} / \mathrm{H}_{2} \mathrm{O}_{2}$ and $\mathrm{UV} / \mathrm{Fe} / \mathrm{H}_{2} \mathrm{O}_{2}$ (Master's thesis, Middle East Technical University). http://etd.lib.metu.edu.tr/upload/ 12623055/index.pdf

Wang F, Wang W, Yuan S, Wang W, Hu ZH (2017) Comparison of UV/ $\mathrm{H}_{2} \mathrm{O}_{2}$ and UV/PS processes for the degradation of thiamphenicol 
in aqueous solution. J Photochem Photobiol, A 348:79-88. https:// doi.org/10.1016/j.jphotochem.2017.08.023

Xiao Y, Zhang L, Zhang W, Lim KY, Webster RD, Lim TT (2016) Comparative evaluation of iodoacids removal by UV/persulfate and $\mathrm{UV} / \mathrm{H}_{2} \mathrm{O}_{2}$ processes. Water Res 102:629-639. https://doi.org/ 10.1016/j.watres.2016.07.004

Yao H, Sun P, Minakata D, Crittenden JC, Huang CH (2013) Kinetics and modeling of degradation of ionophore antibiotics by UV and UV/ $\mathrm{H}_{2} \mathrm{O}_{2}$. J Environ Sci Technol 47(9):4581-4589. https://doi. org/10.1021/es3052685
Yao Y, Li M, Yang Y, Cui L, Guo L (2019) Electrochemical degradation of insecticide hexazinone with $\mathrm{Bi}$-doped $\mathrm{PbO}_{2}$ electrode: Influencing factors, intermediates and degradation mechanism. Chemosphere 216:812-822. https://doi.org/10.1016/j.chemo sphere.2018.10.191

Yu F, Li Y, Han S, Ma J (2016) Adsorptive removal of antibiotics from aqueous solution using carbon materials. Chemosphere 153:365385. https://doi.org/10.1016/j.chemosphere.2016.03.083

Publisher's note Springer Nature remains neutral with regard to jurisdictional claims in published maps and institutional affiliations. 